Full Length Article

\title{
Direct primary brown coal liquefaction via non-catalytic and catalytic co- processing with model, waste and petroleum-derived hydrogen donors
}

\author{
Jakub Frątczak ${ }^{\mathrm{a}, *}$, José M. Hidalgo Herrador ${ }^{\mathrm{a}}$, Jaromír Lederer ${ }^{\mathrm{a}}$, Lee Stevens ${ }^{\mathrm{b}}$, Clement Uguna ${ }^{\mathrm{b}}$, \\ Colin Snape ${ }^{\mathrm{b}}$, José L. Gómez de la Fuente ${ }^{\mathrm{c}}$, Lukáš Anděl ${ }^{\mathrm{d}}$, Petr Svoboda ${ }^{\mathrm{d}}$, Filomena Pinto ${ }^{\mathrm{e}}$ \\ ${ }^{a}$ Unipetrol Centre for Research and Education (UniCRE), Chempark Litvínov, 43670 Litvínov, Czech Republic \\ ${ }^{\mathrm{b}}$ University of Nottingham, Faculty of Engineering, Energy Technologies Building, Triumph Road, Nottingham NG7 2TU, UK \\ c IBERCAT S.L., Faraday, 7 - 28049 Madrid, Spain \\ d Výzkumný ústav pro hnědé uhlí a.s. (VUHU), tř. Budovatelů 2830/3, 43401 Most, Czech Republic \\ e Laboratório Nacional de Energia e Geologia, I.P., Estrada do Paço do Lumiar, 1649-038 Lisboa, Portugal
}

A R T I C L E I N F O

\section{Keywords:}

Direct coal liquefaction

Co-processing

Brown coal

Wastes

Petroleum

Catalysis

\begin{abstract}
A B S T R A C T
Direct coal liquefaction (DCL) seems to be a suitable way to convert low rank coals into liquid fuels, especially when problematic wastes are used together with this feedstock. It is also a solution to become energy independent for many countries which have significant coal resources and limited access to crude oil. The aim of this research was to investigate DCL process by the co-processing of brown coal with model-, petroleum- and waste-derived solvents. The brown coal with and without W, Fe and Mo metals supported on its surface was tested. Thirteen DCL tests with added hydrogen pressure were carried out in the autoclave. These tests were classified in two groups. First group covered reactions using model and petroleum-derived solvents (tetralin, 1methylnaphthalene, light cycle oil (LCO), hydrotreated LCO, C9+ fraction and decalin) with non-impregnated brown coal. Then, LCO was chosen as solvent for carrying out three tests using the metals supported on coal. Finally, waste tires pyrolysis oil was used as a waste-derived solvent for other three tests with molybdenum supported on coal. For tests using LCO, the total amount of direct liquid and n-heptane soluble products was $20 \mathrm{wt} \%$ higher using metal covered brown coal in comparison to unmodified one. The test with the brown coal impregnated by $1 \%$ of molybdenum resulted in the best efficiency, thus this type of coal was chosen as a catalytic feedstock for the tests with waste tires pyrolysis oil.
\end{abstract}

\section{Introduction}

The coal liquefaction process has been developed since the 1930s; German army was using it to produce synthetic fuels because of the conflict restrictions [1]. The basics of the process are well known, however the process is being continuously investigated. Especially now, when the world's petroleum oil resources are located in unstable territories and the demand for petroleum is continuously increasing, processes such as coal liquefaction are coming back into the researchers interest. The coal can be converted into useful compounds by indirect coal liquefaction (ICL) which consists in the coal gasification followed by catalytic conversion of received synthetic gas into clean hydrocarbons and oxygenated transportation fuels, or by direct coal liquefaction (DCL) which can be performed using solvent under hydrogen atmosphere or donor-solvent under inert atmosphere. In both cases, high temperatures and pressures are used. DCL processes are able to generate wider spectrum of chemicals in comparison to the indirect route [2]. Coal liquefaction process strongly depends on the temperature and reaction time obtaining the best yields in the temperature range of $400-450{ }^{\circ} \mathrm{C}$. However there are other factors which affect the DCL process yield such as type of solvent, reaction atmosphere or the coal itself. The solid residues produced after these processes are usually considered as less valuable products than the original coal used as raw material. Moreover, useful chemicals from the extraction of the solid residues can be done, although the obtaining of high liquid products yields are the main targets [3]. From the reaction mechanism's point of view, two major phenomena occurs during the coal liquefaction: cracking reactions of big structures generating radicals promoted by the high reaction temperature and then the saturation of unsaturated compounds by hydrogen derived from the donor solvent or directly from $\mathrm{H}_{2}$. The use of catalysts in DCL process improves the hydrogenation, cracking and removing of heteroatoms from the coal structure [4].

\footnotetext{
* Corresponding author.

E-mail address: jakub.fratczak@unicre.cz (J. Frątczak).
} 